\title{
Stanford Aortic Dissection Classification
}

National Cancer Institute

\section{Source}

National Cancer Institute. Stanford Aortic Dissection Classification. NCI Thesaurus. Code C139040.

The type of aortic dissection present as defined by the Stanford Classification System (Daily PO, Trueblood HW, Stinson EB, Wuerflein RD, Shumway NE. Management of acute aortic dissections. Ann Thorac Surg 1970;10(3):237-247). 